\title{
Sheehan's syndrome: a case report
}

\section{Shazia Ashraf Khan*, Prabha Lala, Wansalan Shullai, Abha Singh}

Department of Obstetrics and Gynaecology, Lady Hardinge Medical College, New Delhi, India

Received: 30 June 2016

Accepted: 05 August 2016

*Correspondence:

Dr. Shazia Ashraf Khan,

E-mail: shaziashrafkhan@rediffmail.com

Copyright: (C) the author(s), publisher and licensee Medip Academy. This is an open-access article distributed under the terms of the Creative Commons Attribution Non-Commercial License, which permits unrestricted non-commercial use, distribution, and reproduction in any medium, provided the original work is properly cited.

\section{ABSTRACT}

Sheehans syndrome or necrosis of pituitary gland is a rare complication of postpartum haemorrhage, initially described in 1937. Sheehans syndrome though rare is still one of the commonest causes of hypopituitarism in developing countries like ours. We present a case of young lady with this syndrome who presented with classical symptoms of hypopituitarism within 1 year of her delivery which was complicated by postpartum haemorrhage.

Keywords: Sheehan's syndrome, Hypopituitarism, Postpartum haemorrhage

\section{INTRODUCTION}

Sheehan's syndrome which was originally described by Sheehans in 1937, occurs as a result of ischaemic necrosis of pituitary gland due to severe postpartum haemorrhage. ${ }^{1}$ The prevalence of Sheehan's syndrome in 1965 was estimated to be 100_200/100,000 women. ${ }^{2}$

Its frequency is decreasing worldwide and it is a rare cause of hypopituitarism in developed countries owing to advances in obstetric care. However, it is still frequent in underdeveloped and developing countries. Though rare, it should be a consideration in any women who has a history of postpartum haemorrhage and who reports with signs and symptoms of pituitary deficiency.

\section{CASE PRESENTATION}

A 32 year old young lady presented with complaints of amennorhoea, failure to lactate and generalised weakness. She had a significant past history of preterm twin vaginal delivery 1 year back which was complicated by severe postpartum haemorrhage (PPH). The patient had a circulatory collapse and was shifted to intensive care unit. PPH was managed conservatively and patient had received 3 blood transfusions. Her generalised condition stabilised and patient was discharged on $8^{\text {th }}$ post-delivery day. One year later patient came to outpatient department with chief complaints of failure to lactate, amenorrhoea. She also had generalised weakness.

The physical examination of the patient was unremarkable. From history a working diagnosis of Sheehan's syndrome was made. Haemogram, Liver function test, Kidney function test, serum electrolytes were all normal. Hormonal profile was done and patient had low levels of TSH, FHS, LH, Prolactin and cortisol. Serum TSH 0.02IU, T3 2pmol/1, T4 4pmol/l, FSH was 1.70, LH 0.53 and Prolactin 3.63, Serum cortisol was 9.5.

Ultrasonography report of pelvis was normal with endometrial thickness of $4 \mathrm{~mm}$. Diagnosis of sheehan's syndrome was made and it was confirmed by MRI brain which showed empty sella turtica. Patient was put on hormone replacement therapy oral contraceptives, thyroxine and prednisolone.

\section{DISCUSSION}

Sheehan's syndrome is characterised by varying degrees of anterior pituitary dysfunction due to ischaemic necrosis of pituitary gland after massive postpartum haemorrhage. It was first described by Sheehan in 19373. 


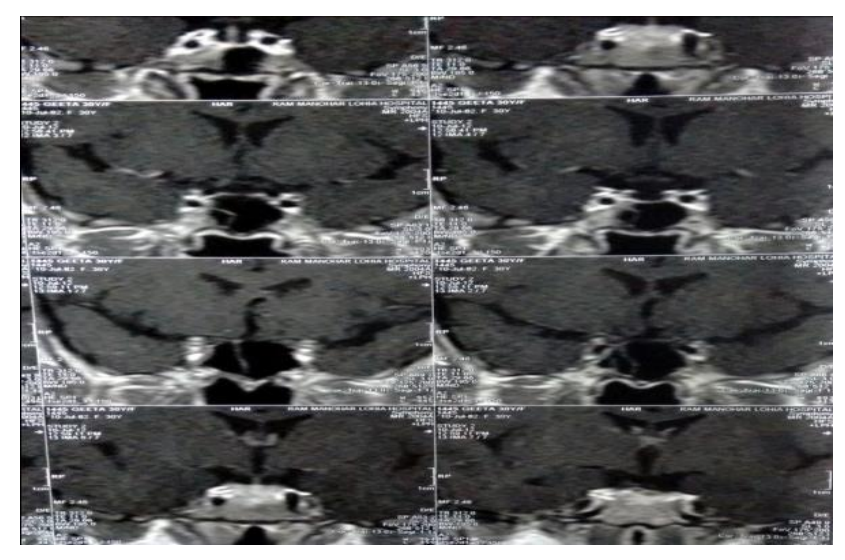

Figure 1(a): MRI (Saggital section) brain of empty sella turtica.

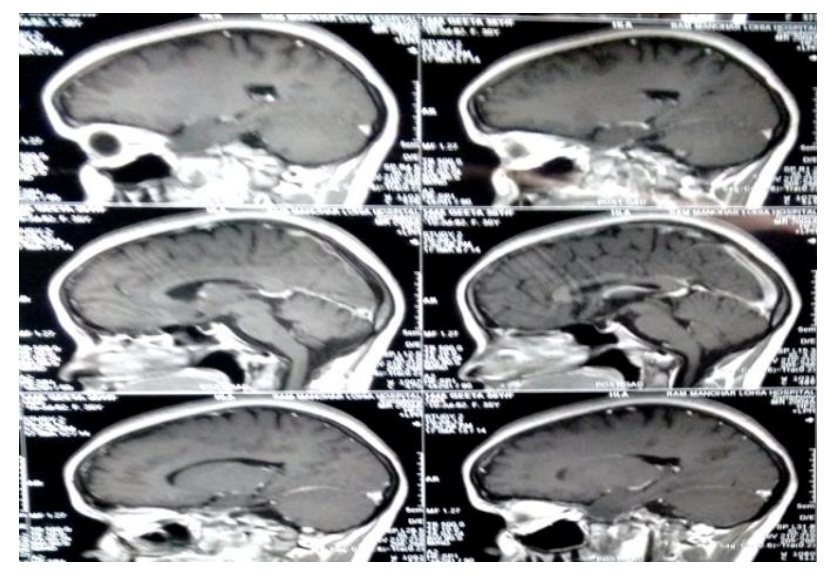

Figure 1(b): MRI (Saggital section) brain of empty sella turtica.

The diagnosis can be made reliably in the presence of lactation failure, prolonged amenorrhoea and hypoglycemic crisis. ${ }^{4}$ However, other signs of pituitary insufficiency are often delayed and subtle leading to diagnosis being missed. The mean duration between postpartum bleeding and subsequent development of symptoms varies between 1 to 33 years. ${ }^{5}$ Clinical features are the result of deficient hormones that may be single or many. Our patient had clinical features consistent with gonadotrophins, and thyroid deficiency. Although failure of postpartum menstruation due to deficiency of FSH and LH is quite common, spontaneous pregnancies have been reported. ${ }^{6}$ Our patient has failed to conceive from last 8 years.
The diagnosis of Sheehan's syndrome is based on the features of hormone deficiency, a suggestive obstetric history and decreased levels of basal hormones (free T3, T4, TSH, FSH, LH, estrogen, prolactin, cortisol, and insulin like growth factor). MRI or CT of pituitary often shows empty sella turtica. Treatment involves lifelong hormone replacement therapy and it is essential to replace the hormones that the pituitary gland fails to produce.

\section{CONCLUSION}

Postpartum pituitary necrosis is a known complication but is now rarely seen. Even if postpartum haemorrhage has been well managed, this complication cannot be excluded. It is necessary to consider this diagnosis in all patients having presented with cardiovascular collapse during childbirth, whatever the cause and in the presence of classical signs of pituitary insufficiency. If not diagnosed early, it could cause increased morbidity and mortality.

\section{Funding: No funding sources Conflict of interest: None declared Ethical approval: Not required}

\section{REFERENCES}

1. Sheehan HI. Postpartum necrosis of the anterior pituitary. Journal of Pathology and Bacteriology. 1937;45:189-214.

2. Sheehan HI. The frequency of postpartum hypopituitarism. Journal of Obstetrics\& Gynaecology of British Common Wealth. 1965;72:103-14.

3. Perraudin V, Lefebvre H, Kuhn JM. Insuffisance antehypophysaire Encycl Med Chi (Paris, Endocrinologiea Nutrition). 1992;10-019-A-10:1-12.

4. Assan R. Urgencies metaboliques et endocriniennes. In: Kleinknecht D, editor principlesde Eeanimation medicates. $3^{\text {rd }}$ ed. Paris: Flammarion Medicine Sciences. 1984:292-326.

5. Huang YY, Ting MK, Hsu BR, Tsai JS. Demonstration of reserved anterior pituitary function among patients with amenorrhoea after postpartum haemorrhage. Gynecol Endocrinol. 2000;14(2):99104.

6. Gokalp D, Tuzzcu A, Bahceci M, Arikan S, Bahceci $\mathrm{S}$, Pasa S. Sheehan's syndrome as a rare cause of anemia secondary to hypopituitarism. Ann Hematol. 2009;88(5):405-10.

Cite this article as: Khan SA, Lala P, Shullai W, Singh A. Sheehan's syndrome: a case report. Int J Reprod Contracept Obstet Gynecol 2016;5:3221-2. 